\title{
Selective bladder preserving treatment by radiation therapy concurrent with either paclitaxel and cisplatin or cisplatin alone following a transurethral surgery
}

\author{
Reham Abdel-Wahab ${ }^{1,2}$, Hoda H. Essa ${ }^{1 *}$, Ahmed Eltaher ${ }^{3}$, Nagham N. Omar ${ }^{4}$ and Mohamed A. Aboziada ${ }^{5}$
}

*Correspondence: hodahassanessa@yahoo.com

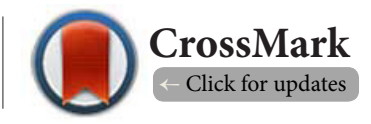

1Departments of Clinical Oncology, Assiut University Hospital, Assiut, Egypt.

${ }^{2}$ Department of Gastrointestinal Medical Oncology, The University of Texas MD Anderson Cancer Center, Houston, Texas, USA.

${ }^{3}$ Department of Urology, Faculty of Medicine, Assiut University, Assiut, Egypt.

${ }^{4}$ Department of Radiology Faculty of Medicine, Assiut University, Egypt.

${ }^{5}$ Department of Radiotherapy, South Egypt Cancer Institute, Assiut University, Assiut, Egypt.

\begin{abstract}
Background: There is a debate regarding the optimal chemotherapeutic regimens that can be used concurrently with radiotherapy (Rth) in muscle invasive bladder cancer (MIBC). Taxanes started to be widely used with evidence of response rates improvement when compared to cisplatin. Our aims were to evaluate the tumor response, treatment toxicity, and disease outcome in MIBC patients who treated with concurrent chemo-radiotherapy (CCRTh) either with paclitaxel and cisplatin or cisplatin alone.

Methods: Between July 2007 and December 2010, sixty T2-4a No Mo bladder cancer patients were enrolled, of whom 55 were eligible for analysis. We randomized our patients into two groups; group I received CCRTh with weekly cisplatin $(\mathrm{n}=25)$ and group II received CCRTH with weekly paclitaxel and cisplatin $(\mathrm{n}=30)$. Kaplan-Meier curve used to estimate overall survival (OS) and recurrence free survival (RFS) with log rank test used to assess the significant difference between patients' subgroups.

Results: A durable complete response (CR) was achieved in $80 \%$ and $86.7 \%$ in groupI and II respectively. The 2-year OS and recurrence free survival (RFS) were $76 \%$ and $61 \%$ for group I, and $85.6 \%$ and $67.2 \%$ for group II, respectively. Multivariate analysis showed that tumor stage was the only survival predictor $(\mathrm{P}<0.0001)$. In both groups, the majority of acute and late toxicities were grade 2 with no treatment-related mortality.
\end{abstract}

Conclusions: Achieving high initial durable CR rates, with acceptable toxicity in both groups; showed that addition of paclitaxel to cisplatin did not significantly add benefit to the treatment outcome.

Keywords: Bladder cancer, paciltaxel, cisplatin, bladder preservation, concurrent chemoradiotherapy

\section{Introduction}

Radical cystectomy (RC) with pelvic lymph node dissection may lead to significant morbidity and affects patients' quality of life (QOL); however it remains the standard treatment approach for muscle-invasive bladder cancer (MIBC) [1,2]. Trimodality bladder-sparing approach; consisting of transurethral resection
(TUR), chemotherapy (CTh) and radiotherapy (RT); induce 50-70\% 5 years overall survival (OS) comparable to those of RC with better QOL [3]. Additionally, salvage cystectomy still an available option for local recurrent cases with acceptable operative complication rates, and excellent long-term disease control and survival outcomes [4]. 
Improvement in radiotherapy techniques such as intensity or volume modulated radiotherapy allow an interesting tumor dose escalation with better tumor control and lesser normal tissue morbidity [5]. Despite that, concurrent administration of chemotherapy with Rth decreased local recurrence rates. It didn't show any evidence of increasing survival, decreasing mortality, or improving in the quality of life [6]. The radiation sensitizing effects of cisplatin are well established and remain a standard of care with cystectomy-free survival rates between $42 \%$ and $55 \%$ at 5 years, depending on the initial tumor stage $[7,8]$. The opportunity to safely enhance this effect by simultaneous administration of a second radiation sensitizer such as fluorouracil or paclitaxel has been a goal [9].

Our study aims to evaluate the tumor response, treatment toxicity, and outcome of patients with muscle invasive bladder cancer treated with CCRth with weekly cisplatin and to assess if the addition of paclitaxel to cisplatin improves treatment outcomes for such patients. Additionally, to detect factors which may predict survival in both groups.

\section{Patients and methods}

Between July 2007 and December 2010, 60 muscle invasive bladder cancer patients were prospectively recruited and treated with CCRth with cisplatin (Platinol, Bristol-Myers Squibb company) with and without paclitaxel (Taxol, Bristol-Myers Squibb company) concurrently with Rth using linear accelerator 6-15 MV. The protocol was approved by the Institutional Review Board at Assiut University and a written consent was taken from all enrolled patients.

\section{Patient selection}

Patients with T2-4a urinary bladder cancer according to the American Joint Committee on Cancer (AJCC) stage [10] and Performance status $<2$ according to European Cooperative Oncology Group (ECOG) [11] enrolled in our study. Initial evaluation included complete blood count (CBC) and serum chemistry, and creatinine clearance, chest radiography, Abdomeno-pelvic computed tomography (CT) scan, and/or MRIand assessment ofbladder capacity. Hemoglobin $>10 \mathrm{gm} /$ dl, white blood cells (WBC) $>4000 / \mathrm{mm} 3$, platelets $>100,000 /$ $\mathrm{mm} 3$, serum creatinine $<2.0 \mathrm{mg} / \mathrm{dl}$, creatinine clearance $>60 \mathrm{ml} /$ $\mathrm{min}$ ), serum bilirubin of $2.0 \mathrm{mg} \%$, and bladder capacity $>350 \mathrm{ml}$ were mandatory. Small residual after second sitting of Maximum transurethral resection of bladder tumor (TURBT) were eligible. Patients were excluded if they have T4b stage, lymph node or distant metastasis, or previously treated with intravesical BCG, chemotherapy or pelvic irradiation.

\section{Non contrast MRI imaging technique}

Imaging was performed by using 1.5 Tesla super conducting image (AchievaPhilipes Health Care) using 16 channel array coil. Special preparation: The patient was advised to drink 2 litres of water before imaging by 2 hours to distend the bladder.

Sequencies used: Non contrast coronal,axial, sagittal T2 $\mathrm{w}$ and axial T1.

\section{Treatment protocol}

Maximal TURBT was performed in one or more attempts. Completeness of TURBT was assessed according to residual tumor status. Complete TURBT was defined as no residual tumor, whereas incomplete TURBT was defined as macroscopic residual tumor. Patients were randomly assigned into to 2 groups; group I $(n=25)$ and group II $(\mathrm{n}=30)$. All patients received combined chemoradiation within 4-6 weeks after the maximal TUR, in two phases.

During Phase I, patients received external radiotherapy in the form of $46 \mathrm{~Gy} / 23$ fractions/41 $\frac{1}{2}$ weeks to whole pelvis; including bladder, the proximal urethra and the pelvic lymph nodes; with concurrent chemotherapy either cisplatin or cisplatin-paclitaxel in group I and II respectively. Subsequently, patients with $>50 \%$ tumor response were shifted to phase II treatment, while Patients with $<50 \%$ tumor response were considered for cystectomy. Thereafter, patients continue into phase II treated with $20 \mathrm{~Gy} / 10$ fractions/ 2 weeks radiation therapy to the bladder only with 1 $\mathrm{cm}$ margin concurrently with the same chemotherapy for each group. By the end of treatment, patients achieved complete response (CR) kept under follow up, while, those with residual tumor considered for radical cystectomy.

Regarding concurrent chemotherapy, in group I patients received weekly cisplatin $40 \mathrm{mg} / \mathrm{m}^{2}$ slow I.V infusion over two hours. While, in group II patients received weekly Cisplatin 20 $\mathrm{mg} / \mathrm{m}^{2}$ and Paclitaxel $60 \mathrm{mg} / \mathrm{m}^{2}$, both administered as a onehour infusion. Paclitaxel was given before Cisplatin to avoid hematological toxicity and proper hydration and antiemetic were used before chemotherapy administration.

\section{Radiotherapy technique Position}

Patients were treated in supine position checked by laser lights. Fixation with thermoplastic shells was used in obese patients and in patients having redundant abdomen. IV contrast was used to localize the bladder. For whole pelvic irradiation (phase I), treatment was given with full bladder to displace the small bowel out of the pelvis. For phase II treatment, the patient was instructed to empty the bladder immediately before the treatment session to ensure that the bladder is inside the target volume. The rectum should be as empty as possible before simulation (may use enema).

\section{Localization}

Field arrangement for the proposed target volume was done by computerized planning system or manual method taking in consideration homogeneous distribution shape to the target volume and the tolerance dose to the critical organs; rectum, small intestine, bilateral femoral head.

\section{Bladder target volume}

This volume included the whole bladder volume plus $1-1.5 \mathrm{~cm}$ margin beyond. This volume shaped using cerrobend blocks.

\section{Pelvic target volume}

This volume included the bladder, the prostate and the prostatic 
urethra (in men) and the regional lymph nodes (perivesical lymph node, distal hypogastric, external iliac vessels and those within the obturator space). The field margins of planning target volume (PTV) in the cranio-caudal dimension extended from S1-S2 junction to the lower pole of the obturator foramen. In the anterior and posterior pelvic field, PTV widths extended 1.0 $\mathrm{cm}$ lateral to the bony margin of the pelvis at its widest point. The anterior border lies $1-2 \mathrm{~cm}$ in front of the anterior bladder wall and the posterior border at the mid-rectum. This volume shaped by using cerrobond blocks.

\section{Radiation dose and energy}

The radiotherapy course deliverd 46 Gy to the pelvic fields, 66 Gy to whole bladder. All doses prescribed at the isocenter, using linear accelerator 6-15 MV. Total dose did not exceed 45 Gy and $50 \mathrm{~Gy}$ to the femoral heads and the posterior rectal wall respectively.

\section{Re-evaluation and Follow up}

During treatment, weekly evaluation by Complete blood counts was performed before each chemotherapy administration. Additional laboratory investigations were done every 3 weeks included electrolytes, liver function, and kidney functions.

Re-evaluation after phase I and 3-4 weeks after phase II was done by pelvic CT and/or MRI, urine cytology, and TURBT. Patients were considered to have achieved CR if there was no evidence of visible tumor on cystoscopy and both biopsy and urine cytology showed no malignancy. Patients with any residual tumor at the original tumor site or muscle-invasive tumor $\geq \mathrm{T} 2$ at a new site were considered candidates for salvage cystectomy.

During CCRTh, the National Cancer Institute Common Toxicity Criteria (NCI-CTC) version 2.0 was used for acute toxicity grading [12]. While, for late toxicity The Radiation Therapy Oncology Group (RTOG) Late Radiation Morbidity Scoring Criteria was used for assessment. After completing the treatment protocol monthly follow-up visit was done during the first 6 months, then every 2 month during the rest of the first year then every 3 months thereafter. History and physical examination were done at each visit, chest $\mathrm{x}$-ray and abdominal pelvic CTand/ or MRI every 3 months or when indicated, and cystoscopy every 6 months or when indicated.

\section{Statistical methods of analysis}

We used IBM SPSS Statistics for Windows, Version 21.0 (IBM Corp., Armonk, NY) for data management and statistical analysis. Univariate analysis was done using chi-square or Fisher's exact test for categorical variables and the Kruskal-Wallis test for continuous variables. The Kaplan-Meier method was used to estimate the median overall survival (OS); which was defined as the time interval between the date of diagnosis and the date of death or last follow-up, disease free survival (DFS); which was defined as the time between treatment end date and the date of documented disease recurrence, death from cancer and/or last follow-up (censored). The comparisons for various endpoints were performed using log rank test and Cox regression analysis was used to detect predictors of survival.

\section{Results}

Among 60 muscle invasive bladder cancer patients, 55 patients (25, group I; 30 , group II) were evaluable for response (2 patients died of non-cancer comorbidities shortly after starting treatment, and 3 patients refused to complete treatment). Table 1 highlights the statistically significant variations in patient characteristics between the two cohorts. Notably, $80 \%$ of group I patients were smokers compared to only $33.3 \%$ in group II with $P$ value 0.001 . Additionally, in group I $64 \%$ had $3-5 \mathrm{~cm}$ tumor size and $40 \%$ had stage T2b compared to $60 \%$ had $<3 \mathrm{~cm}$ tumor size and $50 \%$ presented with stage T2a in group II with P value 0.003 and 0.04 respectively. Furthermore, completed TUR was achieved in 18patients (72\%) in group I and 20 patients (66.7\%) in group II.

\section{Tumor response and salvage treatment}

Urologic evaluation after phase I revealed CR in 16 patients (64\%) and 23 patients (76.7\%) and partial response (PR) in 5 patients $(20 \%)$ and 5 patients (16.7\%) in group I and II respectively. Four patients (16\%) and 2 patients (6.7\%) had Stable disease (SD) or Progressive disease (PD) in group I and II respectively. Patients achieved CR and PR continue phase II and reevaluation at the end of phase II .At end of treatment; 20 patients (80\%) and 26 patients $(86.7 \%)$ had CR and 1 patients (4\%) and 2 patients $(6.7 \%)$ had PR, in group I and II respectively (Table 2 ) and (Figures 7 and 8 ).

\section{Radio-chemotherapy related toxicity Table 3 Early radiation toxicity}

Notably, side effects were tolerable, manageable and most of them were hematological, genitourinary $(\mathrm{GU})$ and gastrointestinal (GI) with no life threatening toxicities detected in both groups. Among 55 patients there were no significant difference between group I and II either in the G1/2 or G3/4 acute toxicity. Regarding the hematological toxicity, 15 patients $(60 \%)$, 20 patients (66.7\%) experienced G1/2, while 1 patient (4\%), 3 patients (10\%) experienced G3/4 in group I and II respectively. Dysuria and frequency were the most frequently observed non hematological toxicities followed by diarrhea. Nine patients (36\%) and 11 patients (36.7\%) experienced G1/2 and 3 patients (12\%), 5 patients (16.7\%) experienced G3/4 GU toxicity in group I and II respectively. Additionally, G1/2 GI toxicity developed in 20 patients (80\%), 22 patients (73.3\%), while 1 patients (4\%), 2 patients (6.7 \%) developed G3/4 in group I and II respectively.

\section{Late Radiation Toxicity}

Within a median follow-up of 26 months (range 12 to 28), the patients showed low incidence of severe late complications. Only one patient in each group had late G3 toxicity and no cases reported G4 toxicity. The major complications were related to the GU system where 16 patients (64\%) in group I and 13 patients (43.3\%) in group II had grade 1/2 toxicity. Notably, there were no treatment-related deaths, and no cystectomies performed 
Essa et al. Journal of Cancer Therapeutics \& Research 2016,

http://www.hoajonline.com/journals/pdf/2049-7962-5-5.pdf

doi: $10.7243 / 2049-7962-5-5$

Table 1. Variations in the epidemiological, risk factors, and clinicopathological characteristics between group 1 (cisplatin treated patients) and group II (cisplatin with paclitaxel treated patients).

\begin{tabular}{|c|c|c|c|c|}
\hline $\begin{array}{l}\text { Patient } \\
\text { characteristic }\end{array}$ & Parameter & $\begin{array}{l}\text { Group 1 } \\
\mathrm{N}=25(\%)\end{array}$ & $\begin{array}{l}\text { Group II } \\
\mathrm{N}=\mathbf{3 0}(\%)\end{array}$ & $P$-value \\
\hline \multirow[t]{3}{*}{ Age (years) } & Mean & 58.8 & 55.6 & -- \\
\hline & $\leq 60$ & $14(56 \%)$ & $20(66.7 \%)$ & 0.6 \\
\hline & $>60$ & $11(44 \%)$ & $10(33.3 \%)$ & \\
\hline \multirow[t]{2}{*}{ Sex } & Male & $20(80 \%)$ & $22(73 \cdot 3 \%)$ & 0.8 \\
\hline & Female & $5(20 \%)$ & $8(26.7 \%)$ & \\
\hline \multirow[t]{2}{*}{ Smoking } & Smoker & $20(80 \%)$ & $10(33.3 \%)$ & 0.001 \\
\hline & Non-smoker & $5(20 \%)$ & $20(66.7 \%)$ & \\
\hline \multirow[t]{2}{*}{ Bilharzias } & Positive & $16(64 \%)$ & $11(36.7 \%)$ & 0.08 \\
\hline & Negative & $9(36 \%)$ & $19(63.3 \%)$ & \\
\hline \multirow[t]{6}{*}{ Complaint } & Hematuria & $17(68 \%)$ & $24(80 \%)$ & 0.9 \\
\hline & Noctnuria & $3(12 \%)$ & $11(36.7 \%)$ & \\
\hline & Dysuria & $3(12 \%)$ & $19(63.3 \%)$ & \\
\hline & $\begin{array}{l}\text { Burning } \\
\text { Micturition }\end{array}$ & $8(32 \%)$ & $4(13.3 \%)$ & \\
\hline & $\begin{array}{l}\text { Increase } \\
\text { Frequency }\end{array}$ & $3(12 \%)$ & $13(43.3 \%)$ & \\
\hline & Pelvic pain & $2(8 \%)$ & $10(33.3 \%)$ & \\
\hline \multirow[t]{2}{*}{$\mathrm{ECOG}^{*}$} & PS_0 & $21(84 \%)$ & $25(83.3 \%)$ & 0.8 \\
\hline & PS_1 & $4(16 \%)$ & $5(16.7 \%)$ & \\
\hline \multirow[t]{7}{*}{ Tumor site } & Anterior wall & $6(24 \%)$ & $1(3.3 \%)$ & 0.9 \\
\hline & Posterior wall & $0(0 \%)$ & $4(13.3 \%)$ & \\
\hline & Lt. Lateral wall & $7(28 \%)$ & $4(13.3 \%)$ & \\
\hline & Rt. Lateral wall & $5(20 \%)$ & $13(43.3 \%)$ & \\
\hline & Bladder dome & $0(0 \%)$ & $3(10 \%)$ & \\
\hline & Bladder neck & $1(4 \%)$ & $2(6.7 \%)$ & \\
\hline & Multiple lesions & $6(24 \%)$ & $3(10 \%)$ & \\
\hline \multirow[t]{3}{*}{ Tumor size } & $<3 \mathrm{~cm}$ & $4(16 \%)$ & $18(60 \%)$ & 0.003 \\
\hline & $3-5 \mathrm{~cm}$ & $16(64 \%)$ & $10(33.3 \%)$ & \\
\hline & $>5 \mathrm{~cm}$ & $5(20 \%)$ & $2(6.7 \%)$ & \\
\hline \multirow[t]{6}{*}{ Histopathology } & TCC $^{*}$ & $12(48 \%)$ & $14(46.7 \%)$ & 0.7 \\
\hline & Sq. C. C.* & $8(32 \%)$ & $6(20 \%)$ & \\
\hline & $\begin{array}{l}\text { TCC with Sq. } \\
\text { differentiation }\end{array}$ & $2(8 \%)$ & $8(26.7 \%)$ & \\
\hline & $\begin{array}{l}\text { TCC with } \\
\text { glandular } \\
\text { differentiation }\end{array}$ & $0(0 \%)$ & $2(6.7 \%)$ & \\
\hline & Adenocarcinoma & $2(8 \%)$ & $0(0 \%)$ & \\
\hline & $\begin{array}{l}\text { Anaplastic cell } \\
\text { carcinoma }\end{array}$ & $1(4 \%)$ & $0(0 \%)$ & \\
\hline \multirow[t]{4}{*}{ Stage } & T2a & $4(16 \%)$ & $15(50 \%)$ & 0.04 \\
\hline & $\mathrm{T} 2 \mathrm{~b}$ & $10(40 \%)$ & $7(23.3 \%)$ & \\
\hline & T3a & $5(20 \%)$ & $6(20 \%)$ & \\
\hline & T3b-4 & $6(24 \%)$ & $2(6.7 \%)$ & \\
\hline
\end{tabular}

Continuation of Table 1.

\begin{tabular}{lllll}
\hline $\begin{array}{l}\text { Patient } \\
\text { characteristic }\end{array}$ & Parameter & $\begin{array}{l}\text { Group 1 } \\
\text { N=25 (\%) }\end{array}$ & $\begin{array}{l}\text { Group II } \\
\mathbf{N = 3 0}(\%)\end{array}$ & P-value \\
\hline $\begin{array}{l}\text { Tumor } \\
\text { differentiation }\end{array}$ & $\begin{array}{l}\text { Well } \\
\text { differentiated }\end{array}$ & $3(12 \%)$ & $4(13.3 \%)$ & 0.9 \\
& $\begin{array}{l}\text { Moderately } \\
\text { differentiated }\end{array}$ & $13(52 \%)$ & $14(46.7 \%)$ & \\
& $\begin{array}{l}\text { Poorly } \\
\text { differentiated }\end{array}$ & $9(36 \%)$ & $12(40 \%)$ & \\
& TUR & $24(96 \%)$ & $30(100 \%)$ & 0.9 \\
\hline $\begin{array}{l}\text { Previous } \\
\text { surgery }\end{array}$ & Partial cystectomy & $1(4 \%)$ & $0(0 \%)$ & \\
\hline TUR & Complete & $18(72 \%)$ & $20(66.7 \%)$ & 0.9 \\
& Incomplete & $7(28 \%)$ & $10(33.3 \%)$ & \\
\hline
\end{tabular}

ECOG: Eastern Cooperative Oncology Group; TCC: Transitional Cell Carcinoma; Sq.C.C: Squamous cell carcinoma; TUR: Transurethral resection

Table 2. Treatment responses after phase I and II of concurrent chemoradiotherapy among group 1 (cisplatin treated patients) and group II (cisplatin with paclitaxel treated patients).

\begin{tabular}{lllll}
\hline & \multicolumn{2}{l}{ Group 1 N=25 (\%) } & \multicolumn{2}{l}{ Group II N=30 (\%) } \\
\cline { 2 - 5 } & Phase I & Phase II & Phase I & Phase II \\
\hline CR & $16(64 \%)$ & $20(80 \%)$ & $23(76.7 \%)$ & $26(86.7 \%)$ \\
PR & $5(20 \%)$ & $1(4 \%)$ & $5(16.7 \%)$ & $2(6.7 \%)$ \\
SD and PD & $4(16 \%)$ & -- & $2(6.7 \%)$ & -- \\
\hline
\end{tabular}

CR: Complete response; PR: Partial response; SD: Stable disease; PD: Progressive disease

due to treatment-related toxicity.

\section{Treatment outcome and patterns of failure Table 4}

Of the 46 patients who had CR after completion of treatment, 4 patients (20\%), 2patients (7.7\%) experienced superficial bladder relapse, 3 patients (15\%), 2 patients $(7.7 \%)$ developed muscleinvasive relapse, 2 patients (10\%), 1 patient (3.8\%) developed pelvic recurrence and 1 patient $(5 \%), 1$ patient (3.8\%) developed distant metastases in group I and group II respectively. The median time to bladder relapse was 11 and 13 months for group I

Table 4. Different patterns of Failure with concurrent chemoradiotherapy among complete responders of group I (cisplatin treated patients) and group II (cisplatin with paclitaxel treated patients).

\begin{tabular}{llll}
\hline Variables & $\begin{array}{l}\text { Group 1 } \\
\text { N=20 (\%) }\end{array}$ & $\begin{array}{l}\text { Group II } \\
\text { N=26 (\%) }\end{array}$ & P-value \\
\hline Superficial recurrence & $4(20 \%)$ & $2(7.7 \%)$ & 0.9 \\
Muscle invasive recurrence & $3(15 \%)$ & $2(7.7 \%)$ & \\
Pelvic recurrence & $2(10 \%)$ & $1(3.8 \%)$ & \\
Distant metastasis & $1(5 \%)$ & $1(3.8 \%)$ & \\
\hline
\end{tabular}



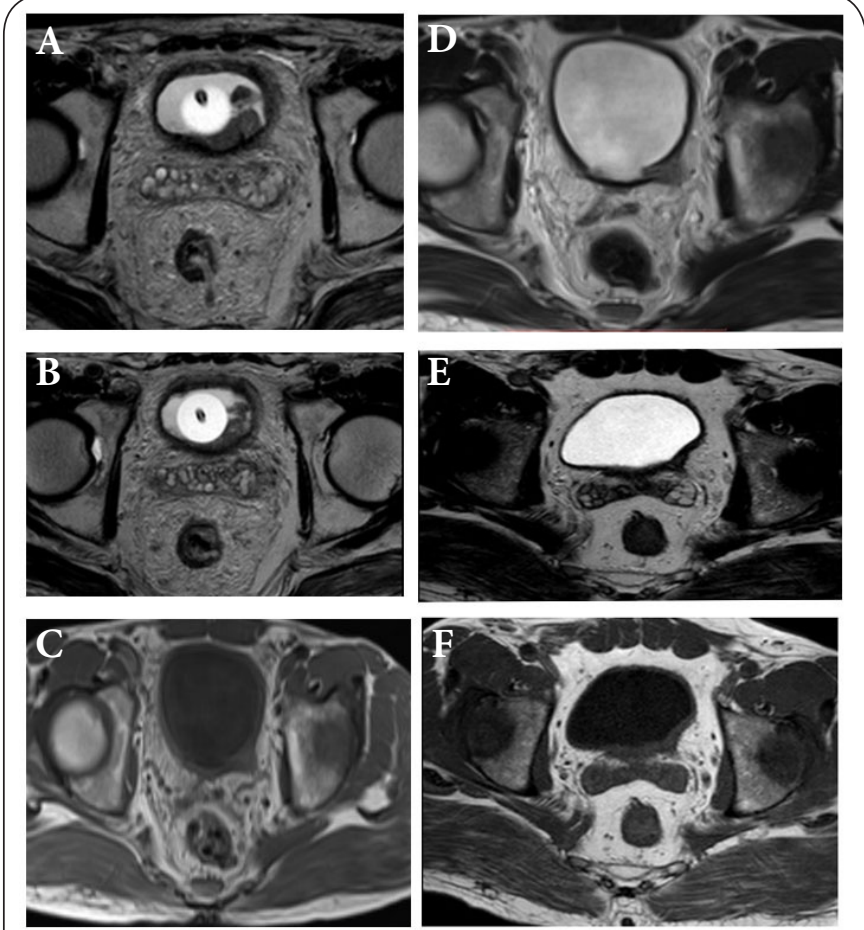

Figure 7.55 years old patient presented with a malignant bladder mass seen at the left posterolaterl wall on MRI axial T2w images $(\mathbf{A} \& \mathbf{B})$ which proved to be transitional cell carcinoma. First phase CCRTH showed partial response on MRI axial T1w image (C) and axial T2w image (D). After the end of treatment there was complete response as seen at axial T2w $(\mathbf{E})$ and $\mathrm{T} 1 \mathrm{w}(\mathbf{F})$. The wall thickening seen is post irradiation effect.

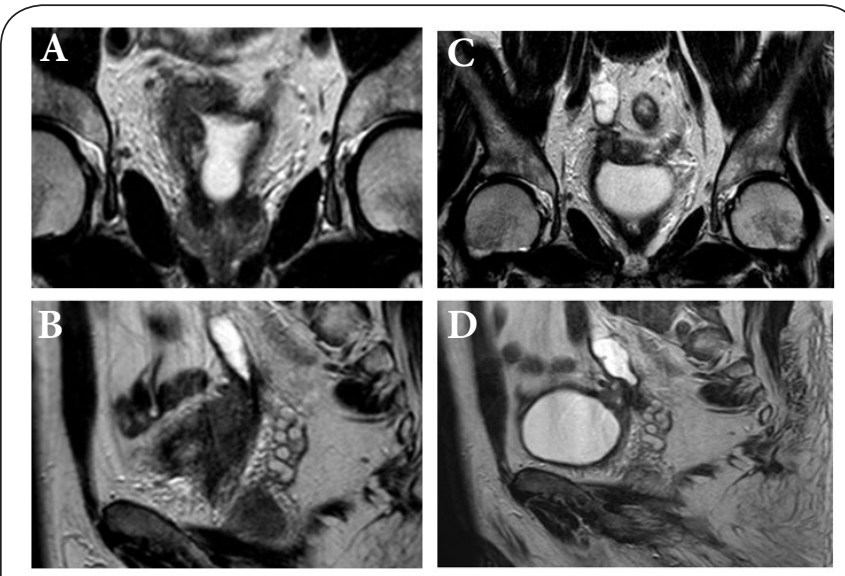

Figure 8. 49 years old patient presented with hematuria. On MRI imaging $(\mathbf{A} \& \mathbf{B})$ coronal and sagittal T2w,a hypo intense right poster lateral bladder mass is seen compressing and evolving the right ureter resulted in proximal dilatation. After CCRTH there was partial remission of the mass as seen on T2w coronal image (C) and T2w sagittal image (D).

and group II, respectively. The median time to distant metastasis was 11 and 12 months for group I and group II, respectively.
There were no significant differences regarding the incidence of superficial recurrences, muscle-invasive relapses, pelvic recurrence and distant metastasis for patients of both groups.

\section{Survival and bladder preservation}

The 2-year overall survival was $76 \%$ and $85.6 \%(\mathrm{P}=0.0 .319)$, while the 2 -year recurrence free survival was $61 \%$ and $67.2 \%$ $(\mathrm{P}=0.134)$ for group I and group II respectively. Subclassifying patients according to the TNM stage showed that patients who have clinical stage T2, the 2-year overall survival rate was $85.7 \%$ and $89.2 \%(\mathrm{P}=0.642)$ and the 2 -year recurrence free survival rate was $63.5 \%$ and $71.3 \%(\mathrm{P}=0.173)$ for group I and group II respectively. For clinical stage $\mathrm{T} 3$, the 2 -year overall survival rate was $61.4 \%$ and $66.7 \%(\mathrm{P}=0.640)$, and the 2 -year Recurrence free survival rate was $59.7 \%$ and $58.3 \%(\mathrm{P}=0.624)$ for group I and group II respectively (Figures 1-6).

Table 5 showed that however performance status $(\mathrm{P}=0.05)$, tumor stage $(\mathrm{P}<0.0001)$, completeness of TUR $(\mathrm{P}=0.04)$, and response to induction treatment $(\mathrm{P}=0.02)$ were the factors significantly correlated with a superior OS. Multivariate analysis (MVA) showed that tumor stage was the only factor significantly associated with OS $(\mathrm{P}<0.0001)$.

\section{Discussion}

Both induction regimens either cisplatin alone or in combination with paclitaxel had high response rate, high rate of bladder preservation, and acceptable toxicity, however the addition of paclitaxel to cisplatin did not add significantly to the treatment outcome.

Tri-modality therapy (TMT) approach including maximal TUR followed by concurrent chemo-radiotherapy is the most studied bladder-sparing modalities. The rationale for CCRTh is that certain cytotoxic agents have the ability to sensitize cancer cells to radiation and inhibit its repopulation during radiotherapy, thus increasing local cure rates. Furthermore, since approximately $10 \%$ of superficially infiltrating tumors and $50 \%$ of muscle-invasive tumors already develop occult metastases, systemic chemotherapy may help to eradicate them [13].

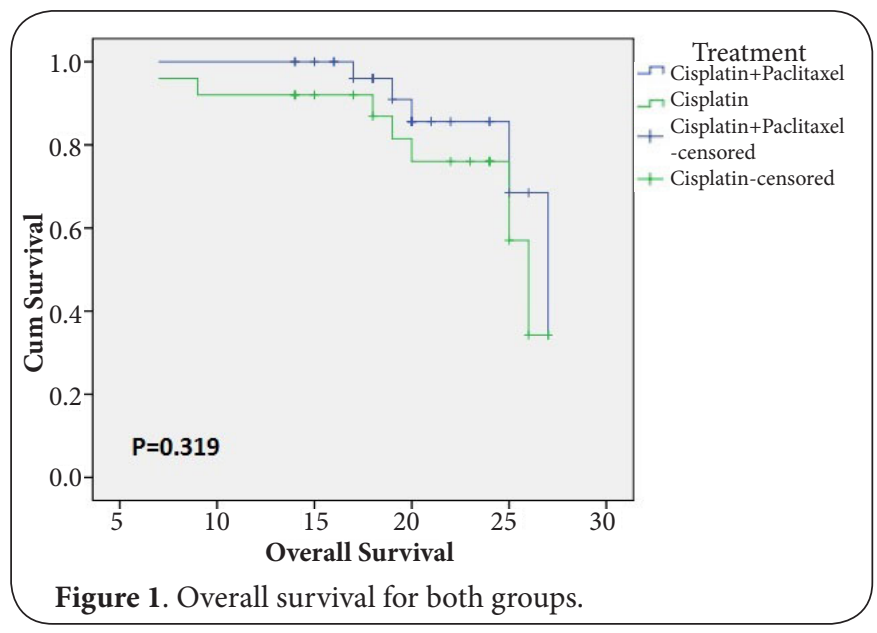


Essa et al. Journal of Cancer Therapeutics \& Research 2016,

http://www.hoajonline.com/journals/pdf/2049-7962-5-5.pdf

doi: $10.7243 / 2049-7962-5-5$

Table 3. Reported toxicities with concurrent chemoradiotherapy among group 1 (cisplatin treated patients) and group II (cisplatin with paclitaxel treated patients).

\begin{tabular}{|c|c|c|c|c|c|c|c|c|}
\hline \multirow[t]{2}{*}{ Variables } & \multicolumn{4}{|c|}{ Group $1 \mathrm{~N}=25(\%)$} & \multicolumn{4}{|c|}{ Group II N=30 (\%) } \\
\hline & G1 & G2 & G3 & G4 & G1 & G2 & G3 & G4 \\
\hline \multicolumn{9}{|l|}{ Early toxicity } \\
\hline Anemia & $3(12 \%)$ & $5(20 \%)$ & $0(0 \%)$ & 0 & $6(20 \%)$ & $5(16.7 \%)$ & $1(3.3 \%)$ & $1(3.3 \%)$ \\
\hline Leucopenia & $4(16 \%)$ & $2(8 \%)$ & $1(4 \%)$ & 0 & $3(10 \%)$ & $2(6.7 \%)$ & $1(3.3 \%)$ & 0 \\
\hline Thrombocytopenia & $1(4 \%)$ & $1(4 \%)$ & $0(0 \%)$ & 0 & $3(10 \%)$ & $2(6.7 \%)$ & 0 & 0 \\
\hline Diarrhea & $10(40 \%)$ & $3(12 \%)$ & $1(4 \%)$ & 0 & $11(36.7 \%)$ & $5(16.6 \%)$ & $1(3.3 \%)$ & 0 \\
\hline Vomiting & $12(48 \%)$ & $5(20 \%)$ & 0 & 0 & $13(43.3 \%)$ & $7(23.3 \%)$ & $2(6.7 \%)$ & 0 \\
\hline Proctitis & $15(60 \%)$ & $3(12 \%)$ & 0 & 0 & $10(33.3 \%)$ & $2(6.7 \%)$ & 0 & 0 \\
\hline Dysuria & $8(32 \%)$ & $8(32 \%)$ & $2(8 \%)$ & 0 & $9(30 \%)$ & $8(26.6 \%)$ & $3(10 \%)$ & 0 \\
\hline Frequency/urgency & $6(24 \%)$ & $5(20 \%)$ & $2(8 \%)$ & $1(4 \%)$ & $10(33.3 \%)$ & $7(23.3 \%)$ & $4(13.3 \%)$ & 1 \\
\hline Radiation dermatitis & $5(20 \%)$ & $1(4 \%)$ & 0 & 0 & $4(13.3 \%)$ & $1(3.3 \%)$ & 0 & 0 \\
\hline Increased creatinine & $5(20 \%)$ & $1(4 \%)$ & 0 & 0 & $3(10 \% 0$ & $1(3.3 \%)$ & 0 & 0 \\
\hline Increased bilirubin & 0 & 0 & 0 & 0 & 0 & 0 & 0 & 0 \\
\hline Increased liver enzymes & 0 & 0 & 0 & 0 & 0 & 0 & 0 & 0 \\
\hline Allergy & $1(4 \%)$ & 0 & 0 & 0 & $2(6.7 \%)$ & 0 & 0 & 0 \\
\hline Hearing impairment & $1(4 \%)$ & 0 & 0 & 0 & $1(3.3 \%)$ & 0 & 0 & 0 \\
\hline Cardiovascular arrhythmia & 0 & 0 & 0 & 0 & $1(3.3 \%)$ & $1(3.3 \%)$ & 0 & 0 \\
\hline \multicolumn{9}{|l|}{ Late Toxicity } \\
\hline Proctitis & $4(16 \%)$ & $1(4 \%)$ & 0 & 0 & $3(10 \%)$ & $1(3.3 \%)$ & 0 & 0 \\
\hline Dysuria & $6(24 \%)$ & $4(16 \%)$ & $1(4 \%)$ & 0 & $6(20 \%)$ & $3(10 \%)$ & $1(3.3 \%)$ & 0 \\
\hline Frequency/urgency & $15(60 \%)$ & $2(8 \%)$ & 0 & 0 & $9(30 \%)$ & $2(6.7 \%)$ & 0 & 0 \\
\hline Increased creatinine & $2(8 \%)$ & $1(4 \%)$ & 0 & 0 & $1(3.3 \%)$ & $1(3.3 \%)$ & 0 & 0 \\
\hline
\end{tabular}

Table 5. Univariate and multivariate cox regression analysis for estimation of survival predictors.

\begin{tabular}{lllll}
\hline Variable & $\begin{array}{l}\text { Univairant } \\
\text { HR (95\% CI) }\end{array}$ & P-value & $\begin{array}{l}\text { Multivariant } \\
\text { HR (95\% CI) }\end{array}$ & ${ }^{\star}$ P-value \\
\hline Age >60 vs. $\leq 60 y$ & $1.2(0.6-2.3)$ & 0.6 & $0.9(0.7-1.6)$ & 0.3 \\
Female vs. Male & $0.98(0.5-2)$ & 0.97 & $0.85(0.5-1.6)$ & 0.4 \\
ECOG 1 vs. 0 & $2.4(1-5.9)$ & 0.05 & $2.3(0.9-4.8)$ & 0.1 \\
TNM Stage T3-4 vs. T2 & $15.4(9.4-22.7)$ & $<0.0001$ & $17.2(10.2-25.7)$ & $<.0001$ \\
TUR incomplete vs. complete & $2.3(1.2-4.7)$ & 0.02 & $1.4(0.6-3)$ & 0.6 \\
Induction response & $2(1.2-3.2)$ & 0.04 & $1.2(0.8-2.1)$ & 0.2 \\
Incomplete vs. complete & & & & \\
\hline
\end{tabular}

ECOG: Eastern Cooperative Oncology Group; TUR: Transurethral resection

Cisplatin is the main chemotherapeutic agent used in bladder preservation protocols [14]. Notably, cisplatin induced good results in terms of cancer control and bladder preservation. Over the years, the researchers started to use combination therapy instead of single agent cisplatin with noticed significantly higher CR rate and longer overall survival rates. The optimum combination of chemotherapeutic drugs needs to be identified not only to improve efficacy but also to minimize toxic effects related to treatment [9].

In our study the rate of CR in group I and II was $80 \%$ and $86.7 \%$ respectively which is comparable to previous studies [15-24], while, other studies showed lower CR rate and this is explained by that the majority of our patients were T2. [9,25-31].
Bladder cancer is a disease of elderly so treatment toxic effects are a concern. The treatment was tolerable with no need for cystectomy subsequent to treatment related toxicities in both groups. The acute toxicities were usually self-limiting or manageable. However, G3/4 acute toxicities reported among both groups were comparable to previous studies $[16,21,24]$.G3/4 toxicities reported in cisplatin-paclitaxel group were lower than the studies that used twice-daily radiotherapy with adjuvant chemotherapy $[31,32]$. Additionally, we reported a low incidence of late pelvic toxicity which is similar to previous studies. Notably, G3 late toxicity in cisplatin-paclitaxel group was lower than that reported by Mitin and his colleague. However this is explained by using hyper fractionated radiotherapy technique [9]. 

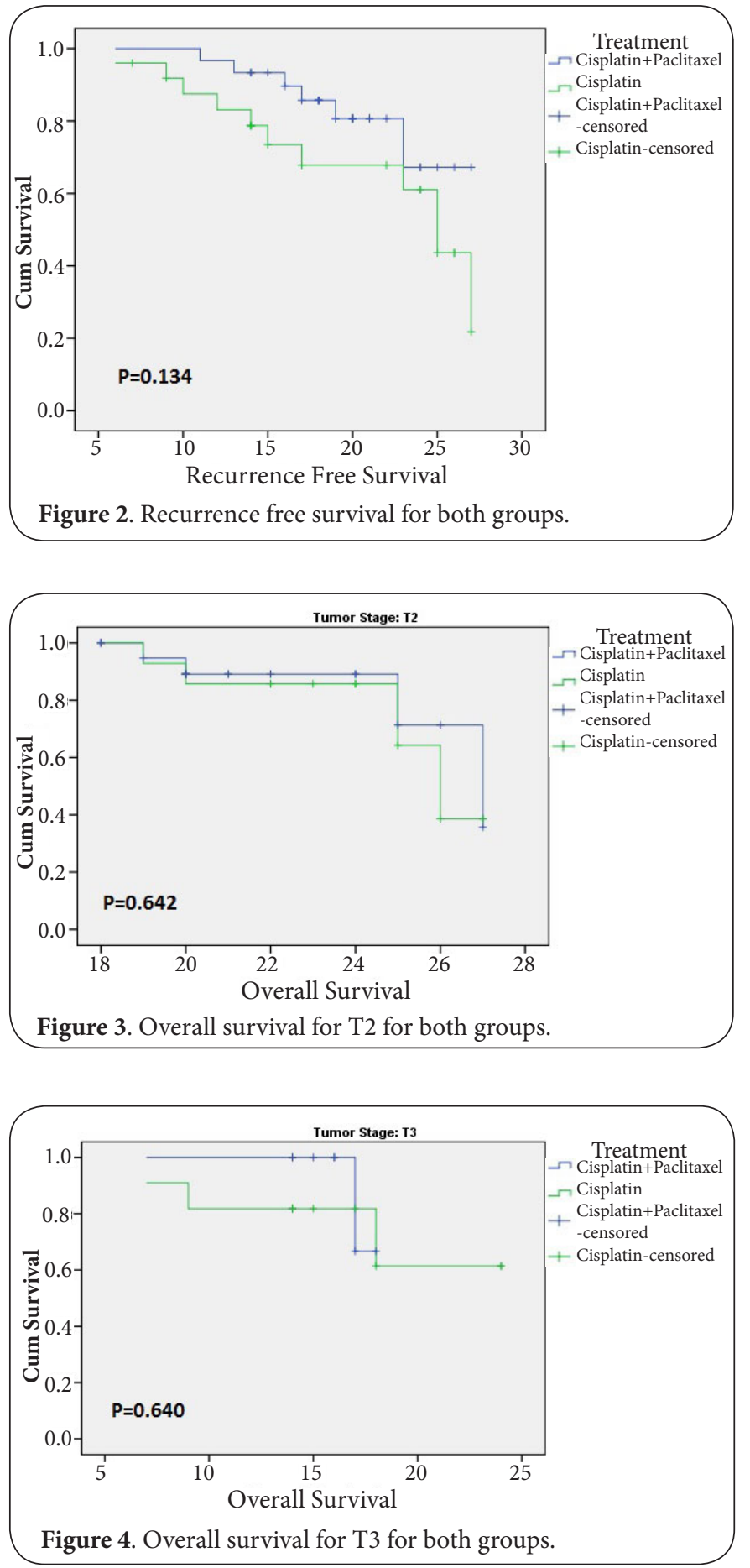

The 5-year survival rate for definitive radiation therapy for muscle invasive bladder cancer was ranging from $30 \%$ to $40 \%$. However, increasing patients' survival is the primary goal of the bladder-sparing approach. Concomitant administration of chemotherapy with radiation therapy only reduce local relapse rates without evidence of increasing survival, decreasing mortality, or improving in the quality of life [6]. Among our groups both OS and RFS results was similar to previously published

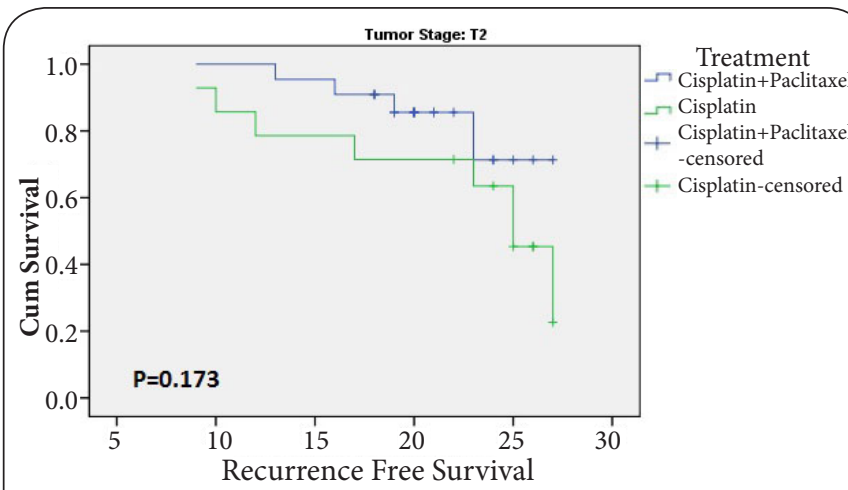

Figure 5. Recurrence free survival for T2 for both groups.

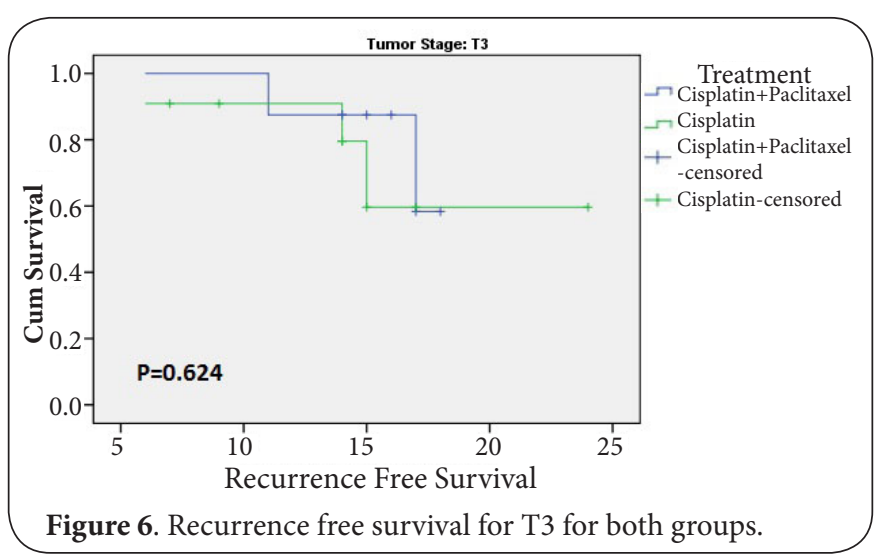

studies [7,19,33-35]. Additionally, the OS of cisplatin-paclitaxel group was comparable to the early reports of RTOG-99-6 [36].

The risk of local recurrence after achievement of $\mathrm{CR}$ ranging from $14 \%$ to $43 \%$ at 5 years .Approximately $60 \%$ of local failures are superficial and $40 \%$ are muscle invasive $[14,21,24,25,34,37-40]$ The rate of local recurrence in our study was within the same range of the previously reported studies. Although, it was reported that the majority of patients developed local recurrences within the first 12-24 months after treatment completion and so patients need to be closely monitored with repeated cystoscopies during this period $[15,30,37,39,41]$. Follow-up should not be limited to the first 2 years as some series reported local recurrences as late as 5-10 years after treatment and some of these patients still had the chance for salvage surgery $[15,39,42]$.

Selection of ideal candidates and the optimal regimens are main concern in bladder-preserving approach. Thus, several studies were done to identify the predictors for ideal candidates for tri-modality treatment. Similar to previous studies $[13-15,18,21,24,33,43,44]$, our study showed that completeness of TUR, PS, response to induction treatment and TNM stage were the main factors affecting survival. However, multivariate analysis showed that TNM staging was the main survival predictor. According to The International Consultation on Urological Diseases, European Association of Urology International, and Consultation on Bladder Cancer, patients with early-stage T2 
disease without any evidence of hydronephrosis, carcinoma in situ (CIS), and tumor invasion into the prostatic stroma are the best candidate for bladder preservation [1]. Regarding the optimal chemotherapeutic regimens, cisplatin and 5-FU still recommended by many physicians based on its radio-sensitizing activities and acceptable toxicities [38]. Recently, taxanes and gemcitabine in combination with platinum are widely used as a neoadjuvant, concurrent or adjuvant settings with evidence of improvement in response rates compared with platinum monotherapy [45].

\section{Conclusion}

Up to our knowledge this is the first randomized study that compared cisplatin with or without taxanes among Egyptian urinary bladder patients. Currently, according to our study in addition to previously published studies, there is no clear clue support one chemotherapy agent over the other with no definite recommendations for the best combination chemotherapy in TMT. However, cisplatin still the cornerstone in treating muscle invasive bladder cancer patients outside clinical trials, biological agents such as trastuzumab are currently under evaluation to be used concurrently with radiation therapy. Further phase III trials should be done to compare between different bladder preservation protocols to achieve longer patients' survival and higher quality of life.

\section{Competing interests}

The authors declare that they have no competing interests.

\section{Authors' contributions}

All authors shared in research design and conduction and analysis of data. The corresponding author (Essa $\mathrm{HH}$ ) wrote the paper and had primary responsibility for final content. All authors read and approved the final manuscript.

\section{Acknowledgement}

The authors thank the patients who consented to participate in this study and their families and carers. We also thank all the colleagues who have collaborated in this study and are not included in the list of authors.

\section{Publication history}

Editors: Jianxun Song, Penn State University, College of Medicine, USA. Satyendra Kumar, University of Illinois at Chicago,USA.

Received: 06 April 2016 Revised: 04 May 2016

Accepted: 02 June 2016 Published: 07 June 2016

\section{References}

1. Gakis G, Efstathiou J, Lerner SP, Cookson MS, Keegan KA, Guru KA, Shipley WU, Heidenreich A, Schoenberg MP, Sagaloswky Al, Soloway MS and Stenzl A. ICUD-EAU International Consultation on Bladder Cancer 2012: Radical cystectomy and bladder preservation for muscle-invasive urothelial carcinoma of the bladder. Eur Urol. 2013; 63:45-57. | Article I PubMed

2. Shabsigh A, Korets R, Vora KC, Brooks $C M$, Cronin AM, Savage $C$, Raj G, Bochner BH, Dalbagni G, Herr HW and Donat SM. Defining early morbidity of radical cystectomy for patients with bladder cancer using a standardized reporting methodology. Eur Urol. 2009; 55:164-74. | Article | PubMed

3. Choudhury A, Swindell R, Logue JP, Elliott PA, Livsey JE, Wise M,
Symonds P, Wylie JP, Ramani V, Sangar V, Lyons J, Bottomley I, McCaul D, Clarke NW, Kiltie AE and Cowan RA. Phase II study of conformal hypofractionated radiotherapy with concurrent gemcitabine in muscleinvasive bladder cancer. J Clin Oncol. 2011; 29:733-8.. | Article | PubMed

4. Chen RC, Shipley WU, Efstathiou JA and Zietman AL. Trimodality bladder preservation therapy for muscle-invasive bladder cancer. J Nat/ Compr Canc Netw. 2013; 11:952-60. | Article | PubMed

5. Beena K, Nambiar VR and Dinesh M. Tri-modality treatment in Muscle Invasive Bladder Cancer-What is the current status? Gen. 2013; 415:1982-2000. I Pdf

6. James N.D, Hussain S.A, Hall E. Radiotherapy with or without chemotherapy in muscle-invasive bladder cancer. N Engl J Med. 2012; 366:1477-1488.

7. Ott OJ, Rodel C, Weiss C, Wittlinger M, St Krause F, Dunst J, Fietkau R and Sauer R. Radiochemotherapy for bladder cancer. Clin Oncol ( $R$ Coll Radiol). 2009; 21:557-65. | Article | PubMed

8. Ploussard G, Daneshmand S, Efstathiou JA, Herr HW, James ND, Rodel $\mathrm{CM}$, Shariat SF, Shipley WU, Sternberg CN, Thalmann GN and Kassouf W. Critical analysis of bladder sparing with trimodal therapy in muscleinvasive bladder cancer: a systematic review. Eur Urol. 2014; 66:120-37. | Article | PubMed

9. Mitin T, Hunt D, Shipley WU, Kaufman DS, Uzzo R, Wu CL, Buyyounouski MK, Sandler $\mathrm{H}$ and Zietman AL. Transurethral surgery and twice-daily radiation plus paclitaxel-cisplatin or fluorouracil-cisplatin with selective bladder preservation and adjuvant chemotherapy for patients with muscle invasive bladder cancer (RTOG 0233): a randomised multicentre phase 2 trial. Lancet Oncol. 2013; 14:863-72. | Article | PubMed Abstract I PubMed FullText

10. Edge SB and Compton CC. The American Joint Committee on Cancer: the 7th edition of the AJCC cancer staging manual and the future of TNM. Ann Surg Oncol. 2010; 17:1471-4. | Article | PubMed

11. Oken MM, Creech RH, Tormey DC, Horton J, Davis TE, McFadden ET and Carbone PP. Toxicity and response criteria of the Eastern Cooperative Oncology Group. Am J Clin Oncol. 1982; 5:649-55. | PubMed

12. Cox JD, Stetz J and Pajak TF. Toxicity criteria of the Radiation Therapy Oncology Group (RTOG) and the European Organization for Research and Treatment of Cancer (EORTC). Int J Radiat Oncol Biol Phys. 1995; 31:1341-6. | Article | PubMed

13. Rodel C, Weiss C and Sauer R. Trimodality treatment and selective organ preservation for bladder cancer. J Clin Oncol. 2006; 24:5536-44. | Article I PubMed

14. Perdona S, Autorino R, Damiano R, De Sio M, Morrica B, Gallo L, Silvestro G, Farella A, De Placido S and Di Lorenzo G. Bladder-sparing, combinedmodality approach for muscle-invasive bladder cancer: a multiinstitutional, long-term experience. Cancer. 2008; 112:75-83. | Article | PubMed

15. Chung PW, Bristow RG, Milosevic MF, Yi QL, Jewett MA, Warde PR, Catton CN, McLean M, Moore M, Tannock IF and Gospodarowicz MK. Long-term outcome of radiation-based conservation therapy for invasive bladder cancer. Urol Oncol. 2007; 25:303-9. | Article | PubMed

16. Gogna NK, Matthews JH, Turner SL, Mameghan H, Duchesne GM, Spry N, Berry MP, Keller J and Tripcony L. Efficacy and tolerability of concurrent weekly low dose cisplatin during radiation treatment of localised muscle invasive bladder transitional cell carcinoma: a report of two sequential Phase II studies from the Trans Tasman Radiation Oncology Group. Radiother Oncol. 2006; 81:9-17. | Article | PubMed

17. Hagan MP, Winter KA, Kaufman DS, Wajsman Z, Zietman AL, Heney NM, Toonkel LM, Jones CU, Roberts JD and Shipley WU. RTOG 97-06: initial report of a phase I-II trial of selective bladder conservation using TURBT, twice-daily accelerated irradiation sensitized with cisplatin, and adjuvant MCV combination chemotherapy. Int J Radiat Oncol Biol Phys. 2003; 57:665-72. | Article | PubMed

18. Joung JY, Han KS, Kim TS, Seo HK, Chung J and Lee KH. Single institutional experience of bladder-preserving trimodality treatment for muscleinvasive bladder cancer. J Korean Med Sci. 2008; 23:598-603. | Article | PubMed Abstract | PubMed FullText

19. Lee CY, Yang KL, Ko HL, Huang RY, Tsai PP, Chen MT, Lin YC, Hwang TI, 
Juang GD and Chi KH. Trimodality bladder-sparing approach without neoadjuvant chemotherapy for node-negative localized muscle-invasive urinary bladder cancer resulted in comparable cystectomy-free survival. Radiat Oncol. 2014; 9:213. | Article | PubMed Abstract | PubMed FullText

20. Lin CC, Hsu CH, Cheng JC, Huang CY, Tsai YC, Hsu FM, Huang KH, Cheng $\mathrm{AL}$ and Pu YS. Induction cisplatin and fluorouracil-based chemotherapy followed by concurrent chemoradiation for muscle-invasive bladder cancer. Int J Radiat Oncol Biol Phys. 2009; 75:442-8. | Article | PubMed

21. Rodel C, Grabenbauer GG, Kuhn R, Papadopoulos T, Dunst J, Meyer M, Schrott KM and Sauer R. Combined-modality treatment and selective organ preservation in invasive bladder cancer: long-term results. $J$ Clin Oncol. 2002; 20:3061-71. | Article | PubMed

22. Sabaa MA, El-Gamal OM, Abo-Elenen M and Khanam A. Combined modality treatment with bladder preservation for muscle invasive bladder cancer. Urol Oncol. 2010; 28:14-20. | Article | PubMed

23. Shipley WU, Winter KA, Kaufman DS, Lee WR, Heney NM, Tester WR, Donnelly BJ, Venner PM, Perez CA, Murray KJ, Doggett RS and True LD. Phase III trial of neoadjuvant chemotherapy in patients with invasive bladder cancer treated with selective bladder preservation by combined radiation therapy and chemotherapy: initial results of Radiation Therapy Oncology Group 89-03. J Clin Oncol. 1998; 16:357683. | Article | PubMed

24. Tester W, Caplan R, Heaney J, Venner P, Whittington R, Byhardt R, True L and Shipley W. Neoadjuvant combined modality program with selective organ preservation for invasive bladder cancer: results of Radiation Therapy Oncology Group phase II trial 8802. J Clin Oncol. 1996; 14:11926. | Article | PubMed

25. Aboziada MA, Hamza HM and Abdlrahem AM. Initial results of bladder preserving approach by chemo-radiotherapy in patients with muscle invading transitional cell carcinoma. J Egypt Nat/ Canc Inst. 2009; 21:167-74. | Pdf | PubMed

26. Arias F, Dominguez MA, Martinez E, Illarramendi JJ, Miquelez S, Pascual I and Marcos M. Chemoradiotherapy for muscle invading bladder carcinoma. Final report of a single institutional organ-sparing program. Int J Radiat Oncol Biol Phys. 2000; 47:373-8. | Article | PubMed

27. Chauvet B, Brewer Y, Felix-Faure C, Davin JL, Choquenet C and Reboul F. Concurrent cisplatin and radiotherapy for patients with muscle invasive bladder cancer who are not candidates for radical cystectomy. J Urol. 1996; 156:1258-62. | Article | PubMed

28. Coppin CM, Gospodarowicz MK, James K, Tannock IF, Zee B, Carson J, Pater J and Sullivan LD. Improved local control of invasive bladder cancer by concurrent cisplatin and preoperative or definitive radiation. The National Cancer Institute of Canada Clinical Trials Group. J Clin Oncol. 1996; 14:2901-7. | Article | PubMed

29. Fellin $G$, Graffer $U$, Bolner A, Ambrosini G, Caffo $O$ and Luciani L. Combined chemotherapy and radiation with selective organ preservation for muscle-invasive bladder carcinoma. A single-institution phase II study. Br J Urol. 1997; 80:44-9. | PubMed

30. Tester W, Porter A, Asbell S, Coughlin C, Heaney J, Krall J, Martz K, Venner $\mathrm{P}$ and Hammond $\mathrm{E}$. Combined modality program with possible organ preservation for invasive bladder carcinoma: results of RTOG protocol 85-12. Int J Radiat Oncol Biol Phys. 1993; 25:783-90. | Article | PubMed

31. Kaufman DS, Winter KA, Shipley WU, Heney NM, Wallace HJ, 3rd, Toonkel LM, Zietman AL, Tanguay S and Sandler HM. Phase I-II RTOG study (99-06) of patients with muscle-invasive bladder cancer undergoing transurethral surgery, paclitaxel, cisplatin, and twice-daily radiotherapy followed by selective bladder preservation or radical cystectomy and adjuvant chemotherapy. Urology. 2009; 73:833-7. | Article | PubMed

32. Cobo M, Delgado R, Gil S, Herruzo I, Baena V, Carabante F, Moreno P, Ruiz JL, Breton JJ, Del Rosal JM, Fuentes C, Garcia E, Villar E, Contreras J, Ales I and Benavides $\mathrm{M}$. Conservative treatment with transurethral resection, neoadjuvant chemotherapy followed by radiochemotherapy in stage T2-3 transitional bladder cancer. Clin Transl Oncol. 2006; 8:903-11. | PubMed

33. Tester W, Porter A, Asbell S, Coughlin C, Heaney J, Krall J, Martz K, Venner $\mathrm{P}$ and Hammond $\mathrm{E}$. Combined modality program with possible organ preservation for invasive bladder carcinoma: results of RTOG protocol 85-12. Int J Radiat Oncol Biol Phys. 1993; 25:783-90. | Article | PubMed

34. Kaufman DS, Winter KA, Shipley WU, Heney NM, Chetner MP, Souhami L, Zlotecki RA, Sause WT and True LD. The initial results in muscle-invading bladder cancer of RTOG 95-06: phase I/II trial of transurethral surgery plus radiation therapy with concurrent cisplatin and 5-fluorouracil followed by selective bladder preservation or cystectomy depending on the initial response. Oncologist. 2000; 5:471-6. | Article | PubMed

35. Zietman AL, Shipley WU, Kaufman DS, Zehr EM, Heney NM, Althausen AF and McGovern FJ. A phase I/II trial of transurethral surgery combined with concurrent cisplatin, 5-fluorouracil and twice daily radiation followed by selective bladder preservation in operable patients with muscle invading bladder cancer. J Urol. 1998; 160:1673-7. | Article | PubMed

36. Kaufman D, Winter K and Shipley W et al. Muscle-invading bladder cancer, RTOG Protocol 99-06: Initial report of a phase I/II trial of selective bladder-conservation employing TURBT, accelerated irradiation sensitized with cisplatin and paclitaxel followed by adjuvant cisplatin and gemcitabine chemotherapy. J ClinOncol. 2005; 23:4506.

37. Housset M, Maulard C, Chretien Y, Dufour B, Delanian S, Huart $\mathrm{J}$, Colardelle F, Brunel $\mathrm{P}$ and Baillet F. Combined radiation and chemotherapy for invasive transitional-cell carcinoma of the bladder: a prospective study. J Clin Oncol. 1993; 11:2150-7. | Article | PubMed

38. Weiss C, Engehausen DG, Krause FS, Papadopoulos T, Dunst J, Sauer R and Rodel C. Radiochemotherapy with cisplatin and 5-fluorouracil after transurethral surgery in patients with bladder cancer. Int J Radiat Oncol Biol Phys. 2007; 68:1072-80. | Article | PubMed

39. Zietman AL, Grocela J, Zehr E, Kaufman DS, Young RH, Althausen AF, Heney NM and Shipley WU. Selective bladder conservation using transurethral resection, chemotherapy, and radiation: management and consequences of $\mathrm{Ta}, \mathrm{T} 1$, and $\mathrm{Tis}$ recurrence within the retained bladder. Urology. 2001; 58:380-5. | Article | PubMed

40. Housset M, Dufour B and Maulard-Durdux C. Concomitant fluorouracilcisplatin and bifractionated split course radiation therapy for invasive bladder cancer. Proc Am SocClinOncol. 1997.

41. Weiss C, Wittlinger M, Engehausen DG, Krause FS, Ott OJ, Dunst J, Sauer $\mathrm{R}$ and Rodel $\mathrm{C}$. Management of superficial recurrences in an irradiated bladder after combined-modality organ-preserving therapy. Int $\mathrm{J}$ Radiat Oncol Biol Phys. 2008; 70:1502-6. | Article | PubMed

42. Cooke PW, Dunn JA, Latief T, Bathers S, James ND and Wallace DM. Longterm risk of salvage cystectomy after radiotherapy for muscle-invasive bladder cancer. Eur Urol. 2000; 38:279-86. | Article | PubMed

43. Danesi DT, Arcangeli G, Cruciani E, Altavista P, Mecozzi A, Saracino B and Orefici $F$. Conservative treatment of invasive bladder carcinoma by transurethral resection, protracted intravenous infusion chemotherapy, and hyperfractionated radiotherapy: long term results. Cancer. 2004; 101:2540-8. | Article | PubMed

44. Shipley WU, Kaufman DS, Zehr E, Heney NM, Lane SC, Thakral HK, Althausen AF and Zietman AL. Selective bladder preservation by combined modality protocol treatment: long-term outcomes of 190 patients with invasive bladder cancer. Urology. 2002; 60:62-7; discussion 67-8. | Article | PubMed

45. Kent E, Sandler H, Montie J, Lee C, Herman J, Esper P, Fardig J and Smith DC. Combined-modality therapy with gemcitabine and radiotherapy as a bladder preservation strategy: results of a phase I trial. J Clin Oncol. 2004; 22:2540-5. | Article | PubMed

\section{Citation:}

Abdel-Wahab R, Essa H.H, Eltaher A, Omar N.N and Aboziada M.A. Selective bladder preserving treatment by radiation therapy concurrent with either paclitaxel and cisplatin or cisplatin alone following a transurethral surgery. J Cancer Ther Res. 2016; 5:5. http://dx.doi.org/10.7243/2049-7962-5-5 